\title{
A sequential aerated peat biofilter system for the treatment of landfill leachate
}

\author{
P. Champagne ${ }^{1} \&$ M. Khalekuzzaman ${ }^{2}$ \\ ${ }^{1}$ Department of Civil Engineering, Queen's University, Canada \\ ${ }^{2}$ Department of Civil and Environmental Engineering, Canada
}

\begin{abstract}
In recent years, researchers have identified peat as an alternative low-cost filter medium for on-site wastewater treatment, including landfill leachate. Peat possesses several physical, chemical and biological characteristics that make it a favorable filter medium for the mitigation of contaminants. The effectiveness and the impact of clogging of peat biofilter in terms of organic $\left(\mathrm{COD}, \mathrm{CBOD}_{5}\right)$, ammonia $\left(\mathrm{NH}_{3}-\mathrm{N}\right)$ and total suspended solid (TSS) loading are crucial in the operation of such systems. The main purpose of this research was to evaluate the performance of a bench-scale sequential aerated peat biofilter system treating landfill leachate at different hydraulic loading rates (HLRs) under continuous flow condition. The system consists of two major components: an aeration chamber with an attached growth media, followed by a peat biofilter. The leachate was aerated at a constant air flow rate of $3.40 \mathrm{~m}^{3} /$ day for a hydraulic retention times (HRTs) of 2 or 5 days. The aerated leachate was then fed to two sets of triplicate peat columns, which were operated at average HLRs of 8.28 $\mathrm{cm}^{3} / \mathrm{cm}^{2} /$ day and $10.82 \mathrm{~cm}^{3} / \mathrm{cm}^{2} /$ day. The result of the study showed that similar $\mathrm{CBOD}_{5}, \mathrm{COD}, \mathrm{NH}_{3}-\mathrm{N}$ and TSS removal efficiencies and column life expectancies could be obtained from the two different hydraulic loading rates to the peat biofilter. However, the HRT in the aeration basin was found to significantly increase the life expectancy of the peat biofilter by reducing the overall contaminant loading to the biofilter. For a HRT of 5 days and constant air flow rate of $3.4 \mathrm{~m}^{3} /$ day $99 \% \mathrm{NH}_{3}-\mathrm{N}$ was removed in the aeration tank after 3 weeks. Removal efficiencies above $80 \%, 90 \%$ and $86 \%$ were noted for COD, $\mathrm{CBOD}_{5}$ and $\mathrm{NH}_{3}-\mathrm{N}$, respectively, in the peat columns after 6 weeks of operation. Keywords: peat, landfill leachate, aeration, biofilm, hydraulic loading, leachate treatment.
\end{abstract}




\section{Introduction}

The Trail Road landfill in the City of Ottawa, commissioned in 1980, generates an average rate of $190 \mathrm{~m}^{3}$ of leachate per day. Currently, leachate from Trail Road landfill is hauled by tanker truck for treatment and discharge at the Robert O. Pickard Environmental Center (ROPEC), the City's wastewater treatment facility. However, the concentrations of several contaminants of the leachate exceed or closely approach the City's Sewer Use By-law limit, particularly TKN, TSS, $\mathrm{BOD}_{5}, \mathrm{H}_{2} \mathrm{~S}$, boron, chloride, xylene, toluence, and barium. As such, the solid waste disposal facility must pay a surcharge for those contaminants that exceed the City Sewer Use By-Law limits. An on-site treatment system pretreating the landfill leachate could reduce operational costs to the landfill, by bringing the landfill leachate to compliance with the Sewer Use By-law limits.

In recent years, studies (Heavey, [1]; Kinsley et al., [2]; Kennedy and Van Geel, [3]; Lyons and Reidy, [4]; Talbot et al., [5]; Viraraghavan and Ayyaswami, [6]; Rock et al., [7]) have identified peat as an alternative low-cost filter medium for on-site wastewater treatment, including landfill leachate. Peat possesses several characteristics that make it a favorable filter medium for contaminants removal, such as high water holding capacity (Bergeron, [8]), low density (Buttler et al., [9]), large surface area $\left(>200 \mathrm{~m}^{2} / \mathrm{g}\right.$ ) (McLellan and Rock, [10]), high porosity (Mclellan and Rock, [10]; Buttler et al., [9]; Mitsch and Gosselink, [11]), and excellent ion exchange properties (Sharma and Forster, [12]; Mckay, [13]). The properties of peat depend on several factors, including the ambient conditions during its formation, the extent of its decomposition and the method of harvesting (Couillard, [14]). To date, limited information regarding the behavior of peat filter systems under varying contaminant, as well as hydraulic loading rates when operated in a biofilter configuration is available. In addition, the treatment efficiency and the total operational life of the peat filter systems, are vulnerable to varying contaminant loads, particularly organic $\left(\mathrm{COD}, \mathrm{BOD}_{5}\right)$, $\mathrm{NH}_{3}-\mathrm{N}$, and TSS concentrations, as well as hydraulic loading rates.

\section{Methodology}

Contaminant removal efficiency and the total operational life of the peat biofilter system are dependent on organic $\left(\mathrm{COD}, \mathrm{BOD}_{5}\right), \mathrm{NH}_{3}-\mathrm{N}$, and TSS constituent, as well as hydraulic loading rates (HLR). The removal efficiency and operational life of a peat biofilter preceded by an aeration chamber with a support media to promote the growth of an attached biofilm were investigated, under different hydraulic and contaminant loading rates and continuous flow condition. The attached growth medium provides a large active surface area and texture, which can promote the rapid growth of a biofilm, thereby, reducing contaminant loads, particularly $\mathrm{NH}_{3}-\mathrm{N}$ and $\mathrm{BOD}_{5}$, on the peat filter leading to an increase in the operational life of the peat biofilter system. Laboratory investigations were conducted using the bench-scale experimental set-up illustrated in Figure 1. 


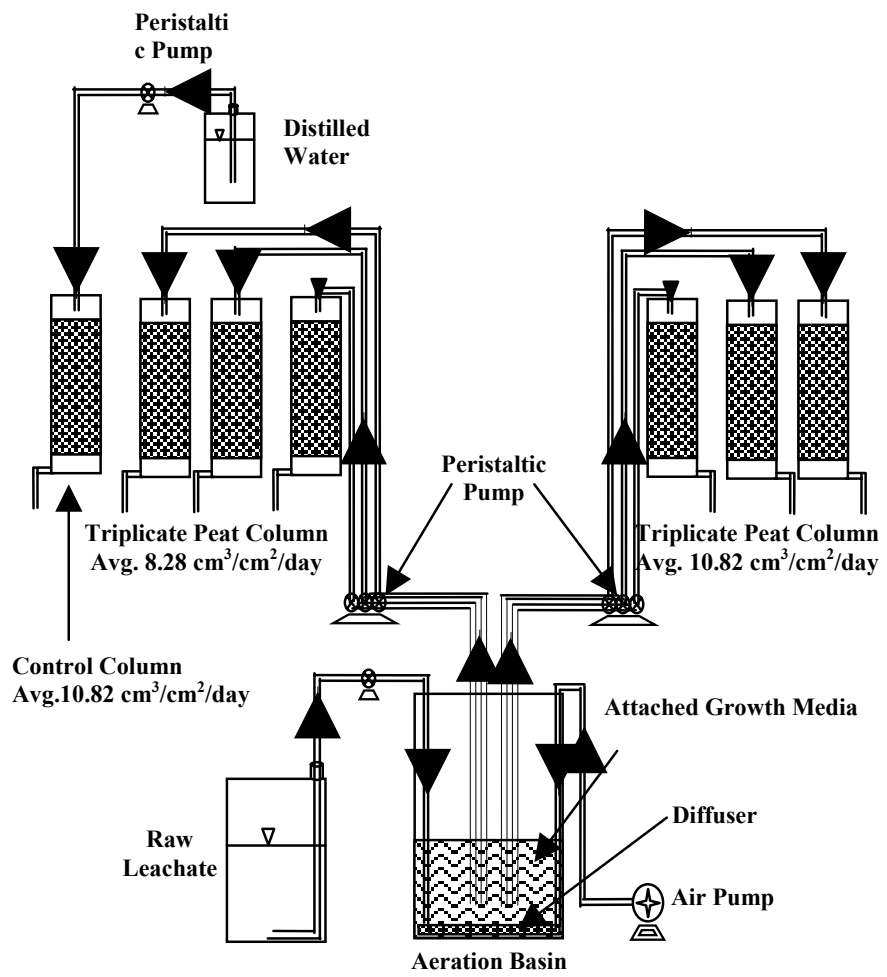

Figure 1: $\quad$ Sequential aerated peat biofilter experimental set-up.

Raw leachate was collected in $20 \mathrm{~L}(28 \mathrm{~cm} \mathrm{X} 23 \mathrm{~cm} \mathrm{X} 40 \mathrm{~cm})$ containers from the City of Ottawa Trail Road landfill and stored in a refrigerators at $4^{\circ} \mathrm{C}$. The raw leachate was passed through a cylindrical aeration tank $(64 \mathrm{~cm} \mathrm{X} 44 \mathrm{~cm}$ ID) using a peristaltic pump at a flow rate $4.5 \mathrm{~L} /$ day, which was equal to the sum of the influent rates of the peat filter columns. An air pump, MAP2X Maxair 2XL, was utilized to inject air into the leachate at a constant air flow rate of $3.40 \mathrm{~m}^{3} /$ day. To aerate effectively, a $28 \mathrm{~cm}$ long perforated hose with a $1 \mathrm{~cm}$ OD was placed at the base of the aeration tank. In addition, a spun plastic medium was used in the aeration basin to get a better performance of the aeration basin by providing a support medium for biofilm growth.

The aerated leachate was fed from the aeration basin to two sets of triplicate peat columns by two sets of peristaltic pumps. One set of triplicate columns was fed at a rate of $8.28 \mathrm{~cm}^{3} / \mathrm{cm}^{2} /$ day, while the other set was fed at a rate of $10.82 \mathrm{~cm}^{3} / \mathrm{cm}^{2} /$ day. Masterflex ${ }^{\circledR}$ TYGON tubing was used to connect each of the stages: from the raw leachate container to the aeration basin, from the aeration basin to the peat column inlet, and from the distilled water container to the control peat column inlet. There were also two calibrated Masterflex ${ }^{\circledR}$ peristaltic pumps, maintaining constant flows from the raw leachate to the aeration basin, and from the distilled water container to the control peat column. Two sets of 
pumps were engaged to feed the two sets of triplicate peat columns with aerated leachate from the aeration basin. Each pump set was assembled with three Masterflex ${ }^{\circledR}$ Easy-Load ${ }^{\circledR}$ pump heads attached to a Masterflex ${ }^{\circledR}$ peristaltic pump to ensure a constant flow rate. The pumps were attached to a GRASSLIN (model CP-924) timer which turned all pumps on intermittently five times a day, for a total of ten minutes per day.

Samples of the raw leachate, aerated leachate and column effluents were collected and analyzed for $\mathrm{COD}, \mathrm{CBOD}_{5}, \mathrm{NH}_{3}-\mathrm{N}, \mathrm{NO}_{3}-\mathrm{N}$, and TSS removal in order to assess the performance of the aeration basin with biofilm growth for contaminants removal at 5-day and 2-day HRTs, as well as the removal efficiencies and life expectancies of the peat biofilters. A blank column was operated with distilled water in the same manner as the higher HLR an average $10.82 \mathrm{~cm}^{3} / \mathrm{cm}^{2} /$ day to observe the potential leaching of constituents from the peat and the behavior of the peat filter under control condition.

The contaminant load in the Trail Road landfill leachate was much higher than is typically reported for untreated domestic wastewater especially in terms of the higher ammonia-N, TSS, COD, and $\mathrm{CBOD}_{5}$ concentration. The average influent COD, $\mathrm{CBOD}_{5}, \mathrm{NH}_{3}-\mathrm{N}, \mathrm{NO}_{3}-\mathrm{N}$, and TSS concentration were $899 \mathrm{mg} / \mathrm{L}$, $340 \mathrm{mg} / \mathrm{L}, 511 \mathrm{mg} / \mathrm{L}, 2 \mathrm{mg} / \mathrm{L}$, and $51 \mathrm{mg} / \mathrm{L}$, respectively for the 5-day HRT. The average influent $\mathrm{COD}, \mathrm{CBOD}_{5}, \mathrm{NH}_{3}-\mathrm{N}, \mathrm{NO}_{3}-\mathrm{N}$, and TSS concentration were $1052 \mathrm{mg} / \mathrm{L}, 534 \mathrm{mg} / \mathrm{L}, 392 \mathrm{mg} / \mathrm{L}, 2 \mathrm{mg} / \mathrm{L}$, and $135 \mathrm{mg} / \mathrm{L}$, respectively, for the 2day HRT. Therefore, these high contaminant concentrations indicate that the leachate is a high-strength wastewater in comparison to municipal wastewater.

\section{Results and discussion}

\subsection{Aeration basin}

The results of this study showed that the aeration basin did not significantly remove COD from the raw leachate for both the 5-day and 2-day HRTs, while $\mathrm{CBOD}_{5}$ concentrations in the aeration basin were observed to decrease from an average $340 \mathrm{mg} / \mathrm{L}$ and $534 \mathrm{mg} / \mathrm{L}$ to $98 \mathrm{mg} / \mathrm{L}$ and $139 \mathrm{mg} / \mathrm{L}$ for the 5 -day and 2-day HRTs, respectively as shown in Figure 2(a). The TSS concentrations of aerated leachate were observed to decrease prior to days 70 and 78 for the 5-day and 2-day HRTs, respectively. Then the TSS concentration of aerated leachate was found to exceeded the raw leachate TSS concentration, which is likely due to the fact that sludge in the aeration basin was not collected and disposed of throughout the course of each experimental HRT (Fig. 2(b)). From Figure 3(a), it can be noted that steady-state removal of $\mathrm{NH}_{3}-\mathrm{N}$ was observed for the 5-day HRT after approximately 2 weeks of operation, while similar $\mathrm{NH}_{3}-\mathrm{N}$ removal was not observed for the 2-day HRT even after 3 weeks of operation. The 5-day HRT also exhibited better nitrification than the 2-day HRT. In addition, an average $\mathrm{NO}_{3}-\mathrm{N}$ generation of $108 \mathrm{mg} / \mathrm{L}$ was found for the 5-day HRT compared to $21 \mathrm{mg} / \mathrm{L}$ for the 2-day HRT (Fig. 3(b)). Denitrification was also noted in the aeration basin after 44 and 42 days of operation for the 5-day and 2-day HRTs, 
Geo-Environment and Landscape Evolution II 129

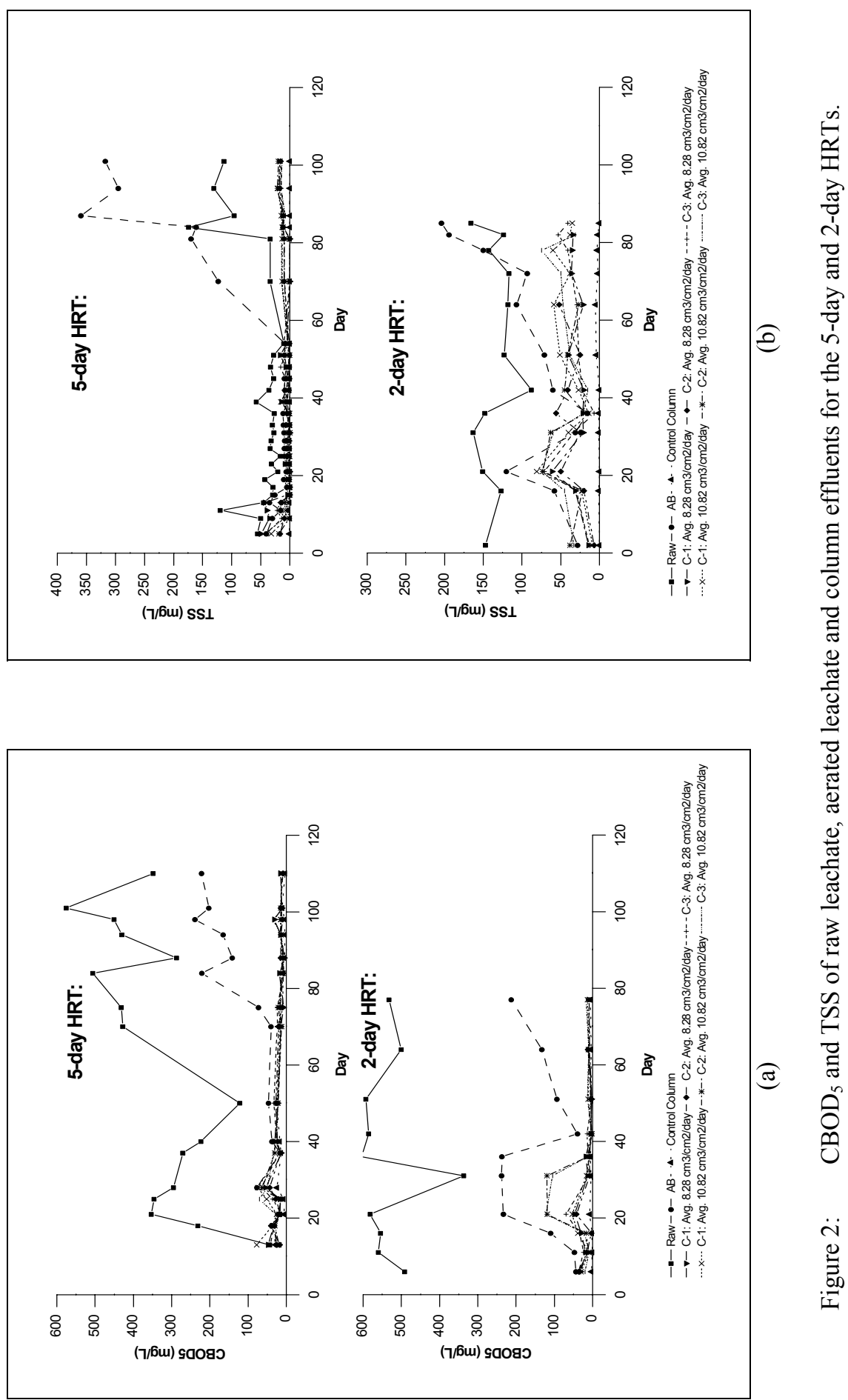

WIT Transactions on Ecology and the Environment, Vol 89, (C) 2006 WIT Press www.witpress.com, ISSN 1743-3541 (on-line) 
130 Geo-Environment and Landscape Evolution II

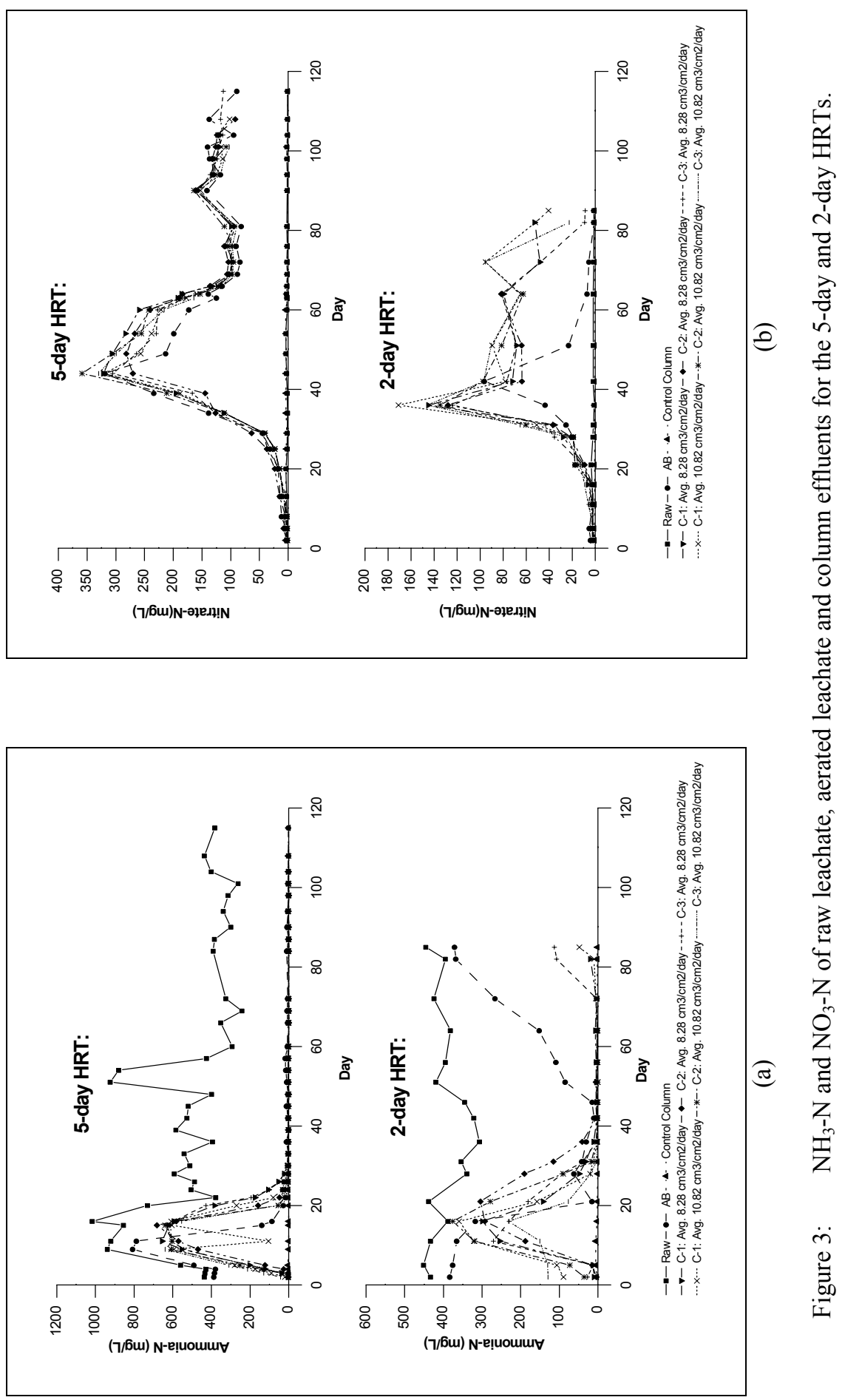

WIT Transactions on Ecology and the Environment, Vol 89, (C) 2006 WIT Press www.witpress.com, ISSN 1743-3541 (on-line) 
respectively. The aeration basin allowed for $\mathrm{NO}_{3}-\mathrm{N}$ removal as a result of the rapid formation of a biofilm onto the attached growth media in the aeration basin. As the microorganisms grow, the thickness of the biofilm layer increase, and the diffused oxygen is consumed before it can penetrate the full depth of the biofilm layer. Thus, an anaerobic environment is established near the surface of the media, which is likely the main mechanism for $\mathrm{NO}_{3}-\mathrm{N}$ removal in the aeration basin after an extended period of operation. The concentration of $\mathrm{NO}_{3}-\mathrm{N}$ was observed to decrease from $319 \mathrm{mg} / \mathrm{L}$ (day 44) and $96 \mathrm{mg} / \mathrm{L}$ (day 42) to $90 \mathrm{mg} / \mathrm{L}$ (end) and $1 \mathrm{mg} / \mathrm{L}$ (end) for the 5-day and 2-day HRTs, respectively.

\subsection{Peat columns}

In this study, two sets of triplicate columns were operated at HLRs of $8.28 \mathrm{~cm}^{3} / \mathrm{cm}^{2} /$ day and $10.82 \mathrm{~cm}^{3} / \mathrm{cm}^{2} /$ day, respectively, for both the 5 -day and 2-day HRTs. The averages of the triplicate column effluents are used in the discussion of the results. The average effluent concentrations from the peat columns were $356 \mathrm{mg} / \mathrm{L}$ and $383 \mathrm{mg} / \mathrm{L}$ at HLRs of $8.28 \mathrm{~cm}^{3} / \mathrm{cm}^{2} /$ day and $10.82 \mathrm{~cm}^{3} / \mathrm{cm}^{2} /$ day, respectively, for the 5-day HRT; while average effluent COD concentrations of $413 \mathrm{mg} / \mathrm{L}$ and $415 \mathrm{mg} / \mathrm{L}$ were observed for the 2-day HRT at the same HLRs. From the control column effluent COD concentrations, it was found that the peat contributed COD to the effluents, with average COD concentrations of $39 \mathrm{mg} / \mathrm{L}$ for both the 5-day and 2-day HRTs. As a consequence, the overall COD removal was limited. Biodegradation of organic matter was observed in the peat columns through $\mathrm{CBOD}_{5}$ removal (Fig. 2(a)). Average effluent $\mathrm{CBOD}_{5}$ concentrations of $22 \mathrm{mg} / \mathrm{L}$ and $24 \mathrm{mg} / \mathrm{L}$ for $8.28 \mathrm{~cm}^{3} / \mathrm{cm}^{2} /$ day and $10.82 \mathrm{~cm}^{3} / \mathrm{cm}^{2} /$ day HLRs, respectively, were noted for the 5-day HRT. Concentrations of $18 \mathrm{mg} / \mathrm{L}$ and $29 \mathrm{mg} / \mathrm{L}$ were obtained for the 2-day HRT, for the $8.28 \mathrm{~cm}^{3} / \mathrm{cm}^{2} /$ day and $10.82 \mathrm{~cm}^{3} / \mathrm{cm}^{2} /$ day HLRs, respectively. Average effluent TSS concentration of $9 \mathrm{mg} / \mathrm{L}$ and $6 \mathrm{mg} / \mathrm{L}$ in 5 -day HRT, and $34 \mathrm{mg} / \mathrm{L}$ and $42 \mathrm{mg} / \mathrm{L}$ in 2-day HRT, were found for the HLRs of $8.28 \mathrm{~cm}^{3} / \mathrm{cm}^{2} /$ day and $10.82 \mathrm{~cm}^{3} / \mathrm{cm}^{2} /$ day, respectively (Fig. 2(b)). The TSS removal was achieved through adsorption and physical filtration via its porous structure. Effluent $\mathrm{NH}_{3}-\mathrm{N}$ concentrations were less than $2.18 \mathrm{mg} / \mathrm{L}$ and $2.15 \mathrm{mg} / \mathrm{L}$ after 30 days of operation at $8.28 \mathrm{~cm}^{3} / \mathrm{cm}^{2} /$ day and $10.82 \mathrm{~cm}^{3} / \mathrm{cm}^{2} /$ day, respectively, for the 5-day HRT (Fig. 3(a)). Comparatively, $\mathrm{NH}_{3}-\mathrm{N}$ effluent concentrations were below $4.29 \mathrm{mg} / \mathrm{L}$ and $5.30 \mathrm{mg} / \mathrm{L}$ after 36 days of operation at $8.28 \mathrm{~cm}^{3} / \mathrm{cm}^{2} /$ day and $10.82 \mathrm{~cm}^{3} / \mathrm{cm}^{2} /$ day, respectively, for the 2-day HRT. The concentrations steadily increased at the end of the experimental run before clogging of the columns were observed. The likely mechanisms of $\mathrm{NH}_{3}-\mathrm{N}$ removal were adsorption of $\mathrm{NH}_{4}{ }^{+}$onto the peat up to the CEC saturation for $\mathrm{NH}_{4}^{+}$, followed by leaching of $\mathrm{NH}_{3}-\mathrm{N}$, nitrification and denitrification. An average, $\mathrm{NO}_{3}{ }^{-} \mathrm{N}$ concentration of $121 \mathrm{mg} / \mathrm{L}$ and $119 \mathrm{mg} / \mathrm{L}$ in 5-day HRT, and $38 \mathrm{mg} / \mathrm{L}$ and $48 \mathrm{mg} / \mathrm{L}$ in 2-day HRT were observed for the HLRs of $8.28 \mathrm{~cm}^{3} / \mathrm{cm}^{2} /$ day and $10.82 \mathrm{~cm}^{3} / \mathrm{cm}^{2} /$ day, respectively (Fig. 3(b)). Denitrification in the peat columns was generally observed after 49 and 36 days of operation; this might be due to the formation of anoxic zones at the bottom of the columns. 
One of the main objectives of this research was to investigate the lifetime of the peat biofilter system under different contaminant loadings, HRT in aeration basin, as well as hydraulic loading rate. The operational life of each of the peat filters was defined as the number of days of operation between when the peat columns were initially fed with leachate to the time clogging was observed as exhibited by surface ponding. The total cumulative $\mathrm{COD}, \mathrm{BOD}_{5}$, and TSS removal of peat columns at the time of clogging for the two sets of triplicate columns were computed under the different operational conditions. The results are summarized in Figure 4 and Table 1.

A single factor ANOVA was conducted with an alpha value of 0.05 to statistically compare the performances of peat columns operated under different conditions. The results of this study indicated that statistically similar total cumulative organic $\left(\mathrm{COD}, \mathrm{CBOD}_{5}\right)$ removals were observed in the peat columns under different HLRs and HRTs since the $\mathrm{F}$ values were always less then $\mathrm{F}_{\text {critical }}$ values in the ANOVA test. However, the higher 5-day HRT of the aeration basin increased the operational life of the peat biofilters when compared to the 2-day HRT through the lowering of the contaminant loading onto peat biofilters.

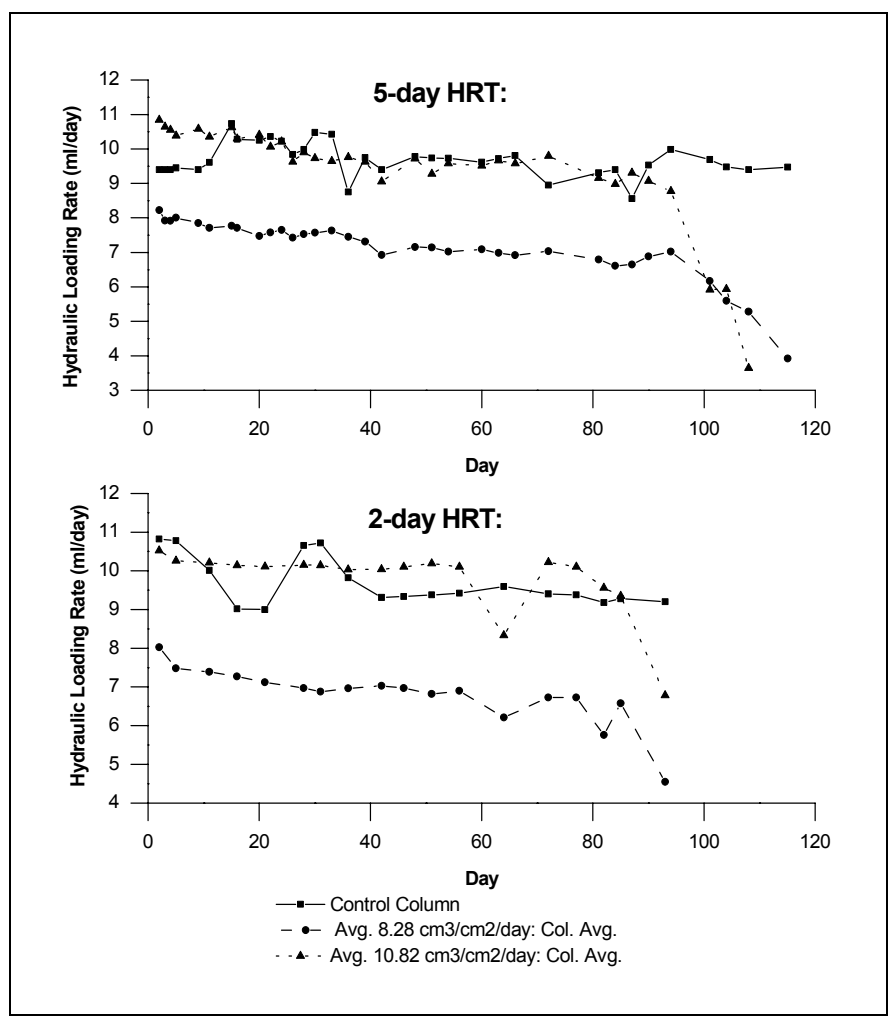

Figure 4: Operational life and cumulative contaminant removal of peat columns. 
Table 1: Operational life and cumulative contaminants removal of peat filters.

\begin{tabular}{|c|c|c|c|c|c|c|}
\hline \multirow{2}{*}{ Phase } & \multirow{2}{*}{\multicolumn{2}{|c|}{$\begin{array}{l}\text { Column } \\
\text { ID }\end{array}$}} & \multirow{2}{*}{$\begin{array}{c}\text { Total } \\
\text { Operational } \\
\text { Life } \\
\text { (day) }\end{array}$} & \multicolumn{3}{|c|}{$\begin{array}{c}\text { Cumulative Removal } \\
\text { (mg/g of Peat) }\end{array}$} \\
\hline & & & & COD & BOD & TSS \\
\hline \multirow{7}{*}{ 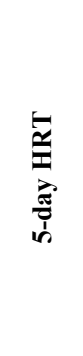 } & \multicolumn{2}{|c|}{ Controlled Column(DW) } & No Clogging & - & - & - \\
\hline & \multirow{3}{*}{$\begin{array}{c}\text { Avg. } 8.28 \\
\mathrm{~cm}^{3} / \mathrm{cm}^{2} / \text { day }\end{array}$} & Column 1 & 104 & 34.68 & 6.42 & 10.92 \\
\hline & & Column 2 & 108 & 46.88 & 9.42 & 15.28 \\
\hline & & Column 3 & 115 & 48.12 & 8.86 & 15.59 \\
\hline & \multirow{3}{*}{$\begin{array}{c}\text { Avg. } 10.82 \\
\mathrm{~cm}^{3} / \mathrm{cm}^{2} / \text { day }\end{array}$} & Column 1 & 108 & 41.31 & 7.54 & 14.96 \\
\hline & & Column 2 & 101 & 48.74 & 10.42 & 16.71 \\
\hline & & Column 3 & 101 & 42.06 & 8.17 & 14.37 \\
\hline \multirow{7}{*}{ 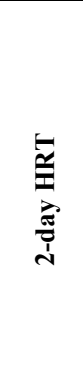 } & \multicolumn{2}{|c|}{ Controlled Column(DW) } & No Clogging & - & - & - \\
\hline & \multirow{3}{*}{$\begin{array}{c}\text { Avg. } 8.28 \\
\mathrm{~cm}^{3} / \mathrm{cm}^{2} / \mathrm{day}\end{array}$} & Column 1 & 82 & 30.04 & 7.65 & 2.91 \\
\hline & & Column 2 & 64 & 20.90 & 5.51 & 1.40 \\
\hline & & Column 3 & 93 & 37.79 & 9.57 & 4.23 \\
\hline & \multirow{3}{*}{$\begin{array}{c}\text { Avg. } 10.82 \\
\mathrm{~cm}^{3} / \mathrm{cm}^{2} / \mathrm{day}\end{array}$} & Column 1 & 93 & 51.68 & 13.50 & 5.20 \\
\hline & & Column 2 & 64 & 31.10 & 5.80 & 1.32 \\
\hline & & Column 3 & 82 & 46.77 & 10.60 & 3.26 \\
\hline
\end{tabular}

\section{Conclusions}

One of the main objectives of this research was to investigate the total operational life of the peat biofilter under varied contaminant loading and hydraulic loading rates. The contaminant loadings to the peat columns were considered to be a function of the HRT in the aeration basin. The results of this research showed that the impact of the hydraulic loading rate was less significant than the effect of contaminant loading rate leading to a longer life of the peat filters. Statistically similar organic $\left(\mathrm{COD}, \mathrm{CBOD}_{5}\right)$ removal performances and life expectancies could be obtained at hydraulic loading rates of $8.28 \mathrm{~cm}^{3} / \mathrm{cm}^{2} /$ day and $10.82 \mathrm{~cm}^{3} / \mathrm{cm}^{2} /$ day in both 5-day and 2-day HRTs. However, the higher HRT, 5 days, increased the life expectancy of the peat biofilter by approximately one month, due to the considerable decrease in the organic, $\mathrm{NH}_{3}-\mathrm{N}$, and TSS loading through the aeration basin. The results also suggested that the contaminant removal efficiencies of the peat biofilter columns were similar for the $8.28 \mathrm{~cm}^{3} / \mathrm{cm}^{2} /$ day and $10.82 \mathrm{~cm}^{3} / \mathrm{cm}^{2} /$ day HLRs.

The results indicated that the peat columns were unstable during the first month of operation, since leaching of COD to effluents by peat itself and saturating of $\mathrm{CEC}$ for ammonia- $\mathrm{N}$ followed by leaching of ammonia-N was observed during the first month of operation. The aeration basin with support 
media for biofilm growth was primarily effective for the removal of $\mathrm{NH}_{3}-\mathrm{N}$ and $\mathrm{NO}_{3}-\mathrm{N}$ through nitrification and denitrification. Steady-state nitrification was initially observed in the aeration basin after approximately 2 to 3 weeks of operation as this was likely the time required for the steady-state development of a biofilm on the attached growth media to which $\mathrm{NH}_{3}-\mathrm{N}$ removal was attributed. Therefore, an anaerobic environment was established near the surface of the media, which was mainly responsible for denitrification in aeration basin after approximately 1.5 months of operation at both the 5-day and 2-day HRTs. From this study, it can be noted that HRT was a limiting factor affecting the contaminants removal efficiencies of aeration basin. Therefore, an increase in HRT would increase the removal of contaminants.

\section{References}

[1] Heavey, M., Low-cost Treatment of Landfill Leachate Using Peat. Waste Management, 23, pp. 447-454, 2003.

[2] Kinsley, C., Crolla, A., \& Fernandez, L., Treatment of Landfill Leachate using a Peat Filter: Final Report. City of Ottawa, Ottawa, ON, 2003.

[3] Kennedy, P. \& Van Geel, P., Hydraulic of Peat Filters Treating Septic Tank Effluent. Transport in Porous Media, 41, pp. 47-60, 2000.

[4] Lyons, H.J. \& Reidy, T.J., The Use of Peat in Treating Landfill Leachate. Humic Substances in Soils, Peats and Waters: Health and Environmental Aspects, eds. M.H.B. Haynes \& W.S. Wilson, UK Royal Society of Chemistry, pp. 475-485, 1997.

[5] Talbot, P., Bélanger, G., Pelletier, M., Laliberté, G., \& Arcand, Y., Development of a Biofilter Using an Organic Medium for On-site Wastewater Treatment. Water Science \& Technol., 34, pp. 435-441, 1996.

[6] Viraraghavan, T. \& Ayyaswami, A., Use of Peat in Water Pollution Control; A Review. Canadian J. of Civil Engineering, 14, pp. 230-233, 1987.

[7] Rock, C.A., Brooks, J.L., Bradeen, S.A., \& Struchtemeyer, R. A., Use of Peat for On-Site Wastewater Treatment: I. Laboratory Evaluation. J. Environ. Qual., 13(4), pp. 518-523, 1984.

[8] Bergeron, M., Peat. Canadian Minerals Yearbook, pp. 37.1-37.8, 1987.

[9] Buttler, A., Dinel, H., \& Levesque, P.E.M., Effects of Physical, Chemical, and Botanical Characteristics of Peat on Carbon Gas Fluxes. Soil Sci., 158(5), pp. 365-374, 1994.

[10] McLellan, J.K. \& Rock, C.A., Pre treating Landfill Leachate with Peat to Remove Metals. Water, Air, \& Soil Pollution. 37; pp. 203-215, 1988.

[11] Mitsch, W.J. \& Gosselink, J.G., Wetlands, Van Nostrand Reinhold Co., New York, 1993.

[12] Sharma, D.C. \& Forster, C.F., Removal of Hexavalent Chromium Using Sphagnum Moss Peat. Water Research, 27(7), pp. 1201-1208, 1993.

[13] Mckay, G., Use of Adsorbents for the Removal of Pollutants from Wastewater, CRC Press, 1996.

[14] Couillard, D., Review: The Use of Peat in Wastewater Treatment. Wat. Res., 28(6), pp. 1261-1274, 1994. 